\title{
Rental Housing: Divorce Or Annulment Of The Parties
}

\author{
Pilar Domínguez Martínez, P.D., University of Castilla-La Mancha, Spain
}

\begin{abstract}
The purpose of increasing the supply in the market lettings Spanish accompanied by greater legal certainty to the parties and protection of tenants has been delivered with the new Law 19/2009, of November 23 amending the rules of urban leases. We analyze the possibility of refusal to extend legal, as long as is contemplated in the contract, when the landlord needs to occupy the house for your spouse in the event of a divorce decree or marriage annulment. This course requires a parallel analysis with the system of judicial allocation of use of the rented family home in cases of separation, annulment and divorce of the tenant.
\end{abstract}

Keywords: Rent, family housing, annulment, divorce, landlord, tenant, denial of renewal

\section{INTRODUCTION}

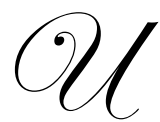

rban leasing legislation, too protectionist for the tenant in respect of the need for family housing reform has been justified operated by Law 19/2009 in order to achieve a balance between the benefits of the parties, just when it comes to protecting the need for family housing in this case the lessor, which favors the other hand increasing the supply of rental housing. Therefore, the present Law refers in its explanatory memorandum to the low occupancy rates for rental (11\%) of the housing market compared to $40 \%$ of the EU average. Indeed, apart from establishing certain energy efficiency measures, the target of the new law was to enhance the rental housing market, first, strengthening the procedural position of landlords against defaulting tenants, speeding up processes eviction in the event of default on lease and on the other, providing the landlord's refusal to extend based on the need for family housing.

The amended paragraph 3 of Article 9 of Law 29/1994, of 24 November, Urban Leases, read as follows: "There shall be no mandatory extension of the contract when, at the time of celebration, stated in the same, express the need for the landlord to occupy the rented premises before the expiry of five years to spend on permanent home for themselves or their families in the first degree of consanguinity or adoption or your spouse in the event of a divorce decree or marriage annulment.

The purpose of promoting the rental of dwellings are set in relation to the need for family housing by providing the landlord can recover the property if needed, not only for him, as happened to this reform, but also for their immediate family members degree by consanguinity or adoption; that first grade is given only on the straight line and never in the collateral, such as children and parents of the lessor, or your spouse in the event of a divorce decree or marriage annulment.

The protection of the family home and the tenant's housing need is reflected in the very definition of rental housing that does the same Urban Leases Act. Rental housing is considered a lease that falls on a residential building whose primary target is to satisfy the continuing need for housing for tenants. The rental housing will not lose this status even if the tenant does not have leased the property in its permanent home, provided that inhabit it are not legally separated spouse or de facto or dependent children. In short, housing has to be familiar.

When the house has the attribute "family" refers not to a single subject but all the individuals who constitute the family. The family as a cell and basic institution of society, is also worthy of special protection by the laws. First, Article art. 39.1 of the EC states that "public authorities ensure social, economic and legal status of 
family." The constitutional protection of the family home is twofold, since it derives not only from its own nature, (right to decent and adequate housing (art. 47 of the EC), but also the destination it serves. (Right to use family). The Supreme Court is described as "family property, no assets, serving the group that settles it, whoever owns them." This protection explains that over time standards have been published have set up special arrangements for the family home that distinguishes the regime applicable to other goods that will lead to a limitation of the property law when it falls on an asset that also affect a primary necessity (art. $47 \mathrm{EC}$ ) is based on marriage. In addition to government regulations protecting the right to decent housing and adequate family housing is a priority.

The legal system protects the family home as a normal part of marriage, as in times of crisis, through the protection of the right of the family to use. In normal situation of marriage, the articles 1320.1357.2 and 1406.4 of the Civil Code. In times of crisis, Article 96 of that Law.For its part, the Urban Leases Act on special rules for leased family housing in Article 12 extends protection to de facto unions, Article 15 as regards the attribution of the use of rented family housing in the cases lessee's marital crisis and finally Article 9.3 amended by Law 19/2009 object of study.

\section{METHODOLOGY}

The reform of the rule comes in response to issues raised by the requirement that the claim of the dwelling by the landlord would be just to himself by a need to own, now extends that possibility need for housing for parents or children, by blood or adoption, and also for the spouse in the event of a divorce decree or annulment, provided that the sentence that constitutes these situations becomes final. The temporal scope of application of the rule is the period of mandatory renewal of the contract, ie the first five years. It is conspicuous by its omission of the situation of need arises in the event of termination facts of married life or when definitive measures are taken in a process of marital separation.

Likewise, the provision does not apply where the situation of need arises after the adoption of provisional measures in proceedings for annulment or divorce by requiring final decision to include the definitive measures It would be desirable to extend the standard case referred to in the second degree relatives (grandchildren and brothers of the lessor) common situations that the rule does not address.

We also extend the course to common situations that occur in circumstances of force majeure occurring or foreseen at the time of conclusion of the contract (divorce, separation, marriage, serious illness, unemployment, etc) to amend the personal status of the lessor or family when you need a home.

This would equate the level of protection of the family of the landlord to the same extent that they are the relatives of the tenant in the LAU. The new standard applies only to the spouse without reference to cases of "permanent living similar emotional relationship to the spouse, regardless of their sexual orientation, as do other provisions of that law in effect when housing family is used on a lease, in cases of abandonment and neglect by the owner, Article 12 of the LAU provides specific protection for the other spouse or cohabitant of the tenant as long as the latter, has been living together two years before the withdrawal or abandonment, except they would have had common ancestry in the event of the lease holder spouse without consent of the other. In case of withdrawal, the owner spouse may take over the other's position, the former owner to have withdrawn. The landlord has the option of requiring the spouse elector, who, not responding to the request within fifteen days, forfeit their right of subrogation as well as being obliged to pay the unpaid rent until the expiry of the contract.

In the case of abandonment of the family home, without the express waiver by the owner, the lease could continue for the spouse of the owner if they live with him, which shall assume the position of the former tenant, provided the within one month after the occurrence of abandonment, the landlord receives written notification of the spouse who chooses to lease, manifesting itself in this regard.

On the other hand, the Urban Leases Act in order to solve the problems of judicial allocation of the use of the rented premises devoted Article 15 to cases of separation, annulment and divorce of the tenant, stating that "the tenant spouse may continue in the use of the rented premises when he is assigned in accordance with Articles 90 and 96 CC. "It provides for allocation of use of the house to the spouse not the lease holder. In addition there must be an 
allocation in the sentence that has terminated the process of annulment, separation or divorce. In this case, the spouse did not use the beneficial owner must notify the landlord will continue in the use of the home.

Notification is mandatory, thus, from knowledge by the landlord of that fact, she intends to take any action against the holder lettings, should also act against the user, should be considered part so that a maneuver is intended to infringe the rights conferred on him the sentence, for example, if the landlord seeks eviction for nonpayment of rent. However, the absence of such notification does not entitle the landlord to terminate the contract.

\section{CONCLUSIONS}

Protecting the right to use the rented premises for the spouse of the lessee contractor in cases of annulment, separation or divorce must correspond with the protection that the landlord does the new rule refers to the need of the landlord to your spouse when has ceased to be, then the sentence must be firm, and cannot share the same house stating why you are leased.

It is true that in the case of Article 15 of the Act, we face the family home for protection but the purpose of the reform of Article 9.3 tends to equal protection of the right to use a house for the family that still exists after marital crisis as it is in this case the lessor. The enlargement of the grounds for refusal of the extension housing needs of the spouse is justified in the case that the use of the family home was attributed to the owner spouse as established by Article 96 of the Civil Code.

It is clear that what generates the need is the judicial allocation of the use, of course, can occur "even in marital separation." It must be said that the need must come from the lessor sentence imposed by fall in the marriage process, after determining the allocation of the use of the family home, would be a need to occupy the rented premises by the spouse of the lessor. The need for the spouse will be determined by the fact that, due to the extent agreed upon in court proceedings concerning the allocation of the use of the family home, must leave it and not have another dwelling which would be used to permanently satisfy their need housing. Nevertheless it could be justified exclusion from the course of separation by the possibility of reconciliation which marred the situation would prevail because in that case the protection of the tenant to meet a need for permanent housing.

On the other hand, the allusion to the process of annulment and divorce strongly suggest a marriage crisis, which has stopped the obligation to live together than to spouses imposed by art. 68 of the Civil Code, which seems to leave out the assumption of exclusion of mandatory renewal cases that force the marriage, the spouse of the lessor need for work or as a second. Anyway, it must be said that this is insufficient reform remains the same dubious evidence of the claim process of need.

It highlights one of the problems of the rental market for landlords: the mandatory renewal of five years. Furthermore, it is curious that the Explanatory Memorandum indicates that this need to be expressed in the contract "to prevent fraud and preserve the necessary legal certainty," when it can be expected that such a clause is contained in most of the contracts hereafter be concluded.

Likewise, referring to a final ruling, does not appear to the legal precept that the need of the spouse of the lessor arising out of the adoption of the measure on the allocation of the use of the family home in so-called interim measures before the petition or in the provisional measures resulting from admission of the application (sections 771 and 773 of the Civil Procedure Act in relation to art. 103.2. nd Civil Code), because they are agreed by order against which no appeal, while the wording of the provision refers only to measures agreed by a final sentence.

In effect, this article refers only to the so-called definitive measures are agreed in the ruling that puts an end to contentious legal proceedings for annulment or divorce (art. 774 of the Civil Procedure Act in relation to art. 96 of the Code Civil) or which are agreed in the Settlement Agreement approved in Case after a procedure called divorce by mutual consent or by one of them with the consent of the other [art. 777 of the Civil Procedure Act in relation to art. 90 c) Civil Code] and only when the judgments become final because they are likely to appeal. 
Although the allocation of the use of the family home is in the sentence or execution of the same (final action), this does not also do in the interim measures (Article 103 of CC) and the previous calls or of provisional (Article 104 of CC) that will last until they are replaced by the final (art. 771 and ff LEC).

In principle, one might think that the use of the family home owner would be the spouse, but the legislature intended that the owner must also not be eligible to continue residing in it. This is because the family home on the family's interests take precedence over individuals of each spouse, as they married, the spouse is not set up expectations holder on the house where both partners also agreed fixed the marital home.

This line has been said by the doctrine that the legislature intended not so much the allocation of rights to use the family home to one spouse, because he already had, such as deprivation of the right to another. Thus through the reform of the Law 19/2009 is to protect the lessor or the lessor's spouse has not been the winner of the use of the family home in a divorce decree or marriage annulment.

If in the case of the family home owned by one spouse only, according to Article 96.3 of the Civil Code, when no children are interested in determining if the spouse has an interest holder in need of protection to decide the allocation at the same exceptional the use of the family home, on equal terms because it is normal to stay with the spouse who is entitled use of them. Similarly, the housing needs of the spouse of the lessor in cases of final decision of annulment or divorce must prevail to the family housing needs of the tenant to justify the refusal of extension.

\section{AUTHOR INFORMATION}

María-Pilar Domínguez-Martínez: Law degree by the Autonomous University of Madrid. Master in Law of Arbitration and Consumer Affairs by the University of Castilla La Mancha, Coordinator Specialist degree in gender violence. Doctor in Civil Law, Professor in civil law and private internacional law department, Faculty of Social sciencies of Cuenca at the University of Castilla La Mancha. (Spain) E-mail: Pilar.Dominguez@uclm.es.

Research Interest: Civil Liability, Family Law.

\section{REFERENCES}

1. $\quad$ Diez Picazo y Gullón, L (2001): Sistema de derecho civil, vol. IV, Tecnos.

2. Herrero García, MJ (1984): “Algunas consideraciones sobre la protección de la vivienda familiar en el código Civil”, Libro homenaje al profesor José Beltrán Heredia y Castaño, 1984, pp. 293 y ss.

3. García Cantero, F (1986): “Configuración del concepto de vivienda familiar en el derecho español”, $E l$ hogar y el ajuar de la familia en las crisis matrimoniales, Bases conceptuales y criterios judiciales, Ediciones Universidad de Navarra, Pamplona.

4. Martín Melendez (2005): Criterios de atribución del uso de la vivienda familiar en las crisis matrimoniales, p. 79.

5. López Azcona, A (2002) La ruptura de las parejas de hecho. Análisis comparado legislativo y jurisprudencial en «Cuadernos de Aranzadi civil», 12, Navarra, 2002.

6. O'Callaghan Muñoz, X (1986) "El derecho de ocupación de la vivienda familiar en las crisis matrimoniales", Actualidad Civil, 1-1986, p. 1339.

7. Pérez Ureña, AA (2003): "La atribución de la vivienda familiar arrendada en la crisis matrimonial. El interés casacional civil. Diez años de Abogados de familia, pp. 495-510

8. Salazar Bort, S (2001): La atribución del uso de la vivienda familiar en las crisis matrimoniales.

9. Tamayo Carmona, J (2003): Protección jurídica de la vivienda habitual de la familia y facultades de disposición, Aranzadi, Navarra. 